\title{
In vitro anti-proliferative activity of alcoholic stem extract of Coscinium fenestratum in human colorectal cancer cells
}

\author{
PIYANUCH ROJSANGA ${ }^{1,2}$, MUGDHA SUKHTHANKAR ${ }^{1}$, CHUTWADEE KRISANAPUN ${ }^{1}$, \\ WANDEE GRITSANAPAN ${ }^{2}$, DARUNEE BURIPAKDI LAWSON ${ }^{3}$ and SEUNG JOON BAEK ${ }^{1}$ \\ ${ }^{1}$ Department of Pathobiology, College of Veterinary Medicine, University of Tennessee, Knoxville, \\ TN, USA; ${ }^{2}$ Department of Pharmacognosy, Faculty of Pharmacy, Mahidol University, Bangkok; \\ ${ }^{3}$ Faculty of Veterinary Science, Mahidol University, Nakornpathom, Thailand
}

Received July 17, 2009; Accepted September 1, 2009

DOI: $10.3892 /$ etm_00000029

\begin{abstract}
Coscinium fenestratum (Gaertn.) Colebr. is traditionally used for the treatment of cancer, arthritis and diabetes mellitus. The purpose of this study was to determine the molecular mechanisms by which this plant shows beneficial effects. An $80 \%$ ethanolic extract of C. fenestratum (80ET) was separated by its polarity into dichloromethane (DCM) and aqueous fractions (WF), and the anti-proliferative effects of 80ET, DCM and WF were investigated. Berberine, one of the major components of $C$. fenestratum, was used as a control. The 80ET, DCM, WF and berberine showed anti-proliferative activity as assessed by cell growth assay. Subsequently, the pro-apoptotic proteins NAG-1 and ATF3 were increased and the cell cycle protein cyclin D1 was decreased by the extract and its fractions. Interestingly, only the DCM fraction exhibited the induction of peroxisome proliferator-activated receptor $\gamma$ (PPAR $\gamma$ ) binding activity, which represents a pro-apoptotic activity in colorectal cancer cells. The overall results of this study indicate that the extract from this plant has anti-proliferative activity through the activation of pro-apoptotic proteins and PPAR $\gamma$, and may have potential as a preventive regimen in the treatment of cancer.
\end{abstract}

\section{Introduction}

Coscinium fenestratum (Gaertn.) Colebr., generally known as Hamm in the Thai language, is a medicinal plant belonging

Correspondence to: Dr Seung Joon Baek, Department of Pathobiology, College of Veterinary Medicine, University of Tennessee, 2407 River Drive, Knoxville, TN 37996, USA

E-mail:sbaek2@utk.edu

Abbreviations: NSAID, non-steroidal anti-inflammatory drug; NAG-1, NSAID-activated gene-1; ATF3, activating transcription factor 3; PPAR $\gamma$, peroxisome proliferator-activated receptor $\gamma$; DCM, dichloromethane; ET, ethanolic extract; WF, aqueous fraction; DMSO, dimethyl sulfoxide

Keywords: Cosciniumfenestratum, non-steroidal anti-inflammatory drug-activated gene-1, activating transcription factor 3, peroxisome proliferator-activated receptor $\gamma$, cyclin D1 to the family of Menispermaceae (1). Decoction and tincture of the stem have been used in ethnomedicine, especially in northeastern Thailand, for the treatment of cancer, diabetes mellitus and arthritis. In addition, this plant has been used in the traditional Ayurvedic and Siddha systems of medicine in India and Sri Lanka for treating diabetes mellitus (2). However, the molecular targets of this plant in anti-cancer activity have not been elucidated.

The non-steroidal anti-inflammatory drug (NSAID)activated gene (NAG-1) was identified in COX-negative cells by PCR-based subtractive hybridization from an NSAID-induced library as a divergent member of the TGF- $\beta$ superfamily (3). The over-expression of NAG-1 in cancer cells results in growth arrest and an increase in apoptosis, suggesting that NAG-1 has anti-tumorigenic activity. NAG-1 expression is also up-regulated by a number of dietary compounds and anticancer drugs (4-8). Similarly, ATF3 is a pro-apoptotic protein, and many anti-tumorigenic compounds, including phytochemicals, induce this protein at the transcriptional level (9). ATF3 has been postulated to be a tumor suppressor gene since it coordinates the expression of genes that may be linked to cancer (10). In contrast, the cyclin D1 proto-oncogene is an important regulator of G1 to $\mathrm{S}$ phase progression in many different cell types (11). Overexpression of cyclin D1 has been described in several forms of human cancer $(12,13)$. A number of therapeutic agents have been observed to suppress cyclin D1 expression in vitro (14-16), indicating that the suppression of cyclin D1 may offer a useful avenue for therapeutic intervention.

Peroxisome proliferator-activated receptor $\gamma(\operatorname{PPAR} \gamma)$ is a ligand-activated transcription factor that regulates numerous biological processes, including energy and lipid metabolism, and cell proliferation (17). The PPAR $\gamma$ agonists can also affect cell proliferation, differentiation and apoptosis in a PPAR $\gamma$ dependent and/or -independent manner, and thereby represent a potentially important therapeutic family of compounds for cancer treatment. Many studies describe the beneficial effects of PPAR $\gamma$ agonists for the treatment of lung (18), ovarian (19), breast (20) and colorectal cancer $(21,22)$. Subsequent study from our laboratory also suggested that PPAR $\gamma$ ligands control many genes that are involved in cellular and physiological pathways in a PPAR $\gamma$-dependent manner (23). In contrast, we have also demonstrated that the PPAR $\gamma$ ligand 
MCC-555 induces NAG-1 and apoptosis in HCT-116 cells (24) in a PPAR $\gamma$-independent manner. In the present study, we investigated the anti-proliferative effects and binding activity for PPAR $\gamma$ of $80 \%$ ethanolic stem extract of C. fenestratum (80ET) and its two additional fractions separated by its polarity, dichloromethane (DCM) and aqueous fractions (WF) of the stem of $C$. fenestratum, as well as berberine, a major constituent of $C$. fenestratum. Our data suggest that the stem extracts extract and its fractions show anti-proliferative activity as assessed by several measurements described here. The antiproliferative activity of the stem extract probably results from berberine; however, the DCM fraction may contain a unique compound that induces PPAR $\gamma$ activity.

\section{Materials and methods}

Plant materials. The dried stems of $C$. fenestratum were obtained from Udonthani province, Thailand, in January 2004. The powdered sample was pharmacognostically identified by us (macroscopic, microscopic and TLC characteristics), as previously reported (25). The voucher specimen was deposited at the Department of Pharmacognosy, Faculty of Pharmacy, Mahidol University, Bangkok, Thailand (WCs04).

Extract preparation. The powdered plant material (100 g) was extracted ten times with $80 \%$ ethanol $(300 \mathrm{ml})$ at room temperature in cycles of $48 \mathrm{~h}$ each on an orbital shaker. The combined extract was evaporated to dryness on a boiling water-bath to yield a dried 80ET. The 80ET was then dissolved in dichloromethane (DCM, 7:300 w/v). The mixture was placed in a separator funnel, and $300 \mathrm{ml}$ of distilled water was added. After shaking, the mixture was thoroughly drained off, allowing the DCM layer to separate. This extraction was repeated three times. The combined DCM and aqueous (WF) layers were collected and evaporated to yield DCM and WF fractions, respectively.

TLC analysis. The content of berberine in the extracts was determined by validated TLC-densitometry as previously described (26). Briefly, $10 \mathrm{mg}$ of the extract was transferred into a $10-\mathrm{ml}$ volumetric flask containing $5 \mathrm{ml}$ methanol, sonicated for $10 \mathrm{~min}$ and diluted to $10 \mathrm{ml}$ with methanol. Filtered on Whatman no. 1 filter paper, a 5- $\mu 1$ aliquot of sample was applied on the precoated silica gel GF254 plate. The plate was then developed with butanol:glacial acetic acid:water (14:3:4), and the analysis was repeated three times. Chromatograms were evaluated via peak area after scanning in absorbance mode at $415 \mathrm{~nm}$. For TLC fingerprint, the extracts extract of $C$. fenestratum and its fractions were dissolved in methanol, and a 5- $\mu$ l sample was applied to the plate, corresponding to $\sim 100 \mu \mathrm{g}$ for each dry weight. A butanol:glacial acetic acid:water (70:15:20) solvent system was used for TLC. The plate was sprayed with Dragendroff's spraying reagent.

Cell cultures, reagents and plasmids. Cell lines were purchased from ATCC (Rockville, MD, USA). The human colorectal carcinoma cell lines HCT-116 and SW480 were maintained in McCoy's 5A and RPMI-1640 medium, respectively, supplemented with $10 \%$ fetal bovine serum (Cellgro, VA,
USA), penicillin and streptomycin (10 mg/ml). 3T3-L1 mouse embryonic fibroblast cells were grown in DMEM. Berberine chloride was purchased from Sigma (St. Louis, MO, USA). Four copies of a Gal4 binding site (MH100x4-TK-LUC) and chimeric receptors (pCMX-Gal-mPPAR $\gamma$-LBD) were previously reported (21). The NAG-1 antibody was previously described (3). ATF3, actin and cyclin D1 antibodies were purchased from Santa Cruz Biotechnology (Santa Cruz, CA, USA). The secondary antibodies linked to HRP were purchased from Cell Signaling Technology (Beverly, MA, USA). All chemicals were purchased from Fisher Scientific, unless otherwise specified.

Cell proliferation analysis. The effects of berberine, 80ET, DCM and WF on cell proliferation in HCT-116 human colorectal cancer cells were investigated using the CellTiter 96 Aqueous One Solution Cell Proliferation Assay (Promega, WI, USA). The cells were seeded at a concentration of 1,000 cells/ well in six replicates and maintained overnight. The cells were then treated with various concentrations of berberine, 80ET, DCM and WF dissolved in dimethylsulfoxide (DMSO) in the presence of serum. At 0, 1, 2 and 4 days after treatment, $20 \mu \mathrm{l}$ of CellTiter96 Aqueous One solution was added to each well and the plate was incubated for $1 \mathrm{~h}$ at $37^{\circ} \mathrm{C}$. An absorbance at $490 \mathrm{~nm}$ was recorded in an enzyme-linked immunosorbent assay (ELISA) plate reader (Bio-Tek Instruments, Winooski, VT, USA).

Western blot analysis. HCT-116 cells were grown to $60-80 \%$ confluence in $6-\mathrm{cm}$ plates followed by a $24-\mathrm{h}$ treatment with various concentrations of berberine, 80ET, DCM and WF, or with DMSO as vehicle control in the absence of serum. Total cell lysates were then isolated using RIPA buffer (1X PBS, $1 \%$ NP-40, $0.5 \%$ sodium deoxycholate, $0.1 \%$ SDS) supplemented with protease inhibitors ( $1 \mathrm{mM}$ PMSF, $5 \mu \mathrm{g} / \mathrm{ml}$ aprotinin and $5 \mu \mathrm{g} / \mathrm{ml}$ leupeptin) and phosphatase inhibitors ( $1 \mathrm{mM} \mathrm{Na}_{3} \mathrm{VO}_{4}$ and $1 \mathrm{mM} \mathrm{NaF}$ ). Protein concentration was determined by the BCA protein assay (Pierce, Rockford, IL, USA), using BSA as the standard. Protein $(30 \mu \mathrm{g})$ was separated by SDS-PAGE and transferred for $1 \mathrm{~h}$ onto a nitrocellulose membrane (Schleicher \& Schuell, NH, USA). The blots were blocked for $1 \mathrm{~h}$ with $5 \%$ skim milk in TBS/Tween $0.05 \%$ (TBS-T) and probed with a specific primary antiserum in TBS-T and 5\% non-fat dry milk at $4{ }^{\circ} \mathrm{C}$ overnight. After washing with TBS-T, the blots were treated with horseradish peroxidase-conjugated secondary antibody for $1 \mathrm{~h}$ and washed several times. Proteins were detected by the enhanced chemiluminescence system.

Transienttransfections. Transient transfections were performed using Lipofectamine (Invitrogen, CA, USA) according to the manufacturer's instructions. HCT-116 cells were plated in 12 -well plates at a concentration of $1 \times 10^{5}$ cells/well. After growth for $18 \mathrm{~h}$, plasmid mixtures containing MH100X 4-TK-LUC plasmid $(0.25 \mu \mathrm{g})$ and pCMX-GalmPPAR $\gamma$-LBD $(0.25 \mu \mathrm{g})$ were co-transfected with pRL-null vector $(0.05 \mu \mathrm{g})$ for $5 \mathrm{~h}$. The transfected cells were cultured in the absence or presence of various concentrations of berberine, 80ET, DCM and WF. Rosiglitazone (RGZ) (Cayman Chemicals, MI, USA; $100 \%$ purity) was used as a positive control. Cells were harvested in $1 \mathrm{X}$ luciferase lysis buffer, and luciferase activity 
A

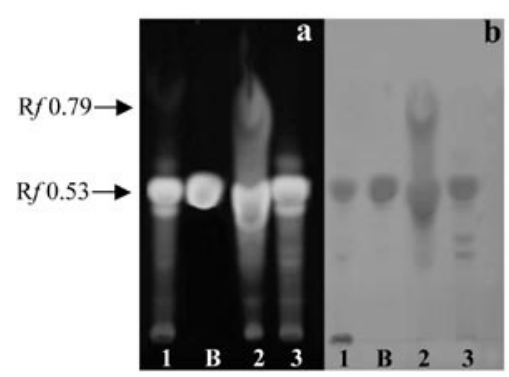

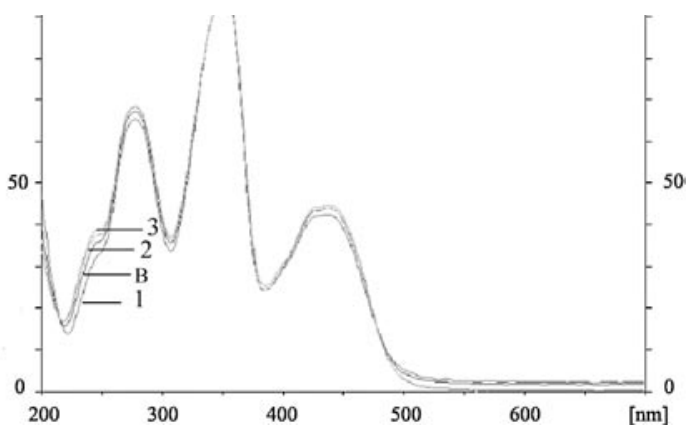

Figure 1. TLC analysis of Coscinium fenestratum extracts. (A) TLC fingerprint. Detection under UV $366 \mathrm{~nm}$ (left panel) and detection with Dragendorff's testing solution (right panel). 1, 80ET; B, berberine; 2, DCM; 3, WF. (B) Spectra comparison of standard berberine and extracts at peak start, peak maximum and peak end in absorbance mode at a wavelength $200-600 \mathrm{~nm}$, captured on the CAMAG TLC Scanner III.

was normalized to the pRL-null luciferase activity using a dual luciferase assay kit (Promega, WI, USA).

Caspase activity. Caspase activity was measured using the Apo-ONE homogeneous Caspase-Glo 3/7 Assay kit (Promega) according to the manufacturer's protocol. Cell lysates $(50 \mu \mathrm{g}$ protein) were obtained using RIPA buffer containing protease inhibitors and incubated with $50 \mu \mathrm{l}$ of Caspase-Glo 3/7 reagent in 96-well plates for $1 \mathrm{~h}$. Luminescence was measured using a plate-reading luminometer (FLX800; BioTek).

3T3-L1 cell differentiation and oil-red $O$ staining. 3T3-L1 cells were grown to confluence in $6 \mathrm{~cm}$-plates. For adipocyte differentiation, differentiation medium (DM) containing $1 \mu \mathrm{g} /$ $\mathrm{ml}$ insulin, $1 \mu \mathrm{M}$ dexamethasone and $0.5 \mathrm{mM}$ isobutylmethyl xanthine was added to the culture. DM was changed every 2 days until day 4. Thereafter, DMEM containing 10\% FBS and insulin only was subsequently replaced every 2 days. DCM $(50 \mu \mathrm{g} / \mathrm{ml})$ was added $24 \mathrm{~h}$ before and during differentiation, and DMSO was used as a vehicle for untreated cells. On day 9, the cells were washed with PBS, fixed with $10 \%$ formalin at room temperature, and stained with oil-red $\mathrm{O}$ for 10 min. Pictures were captured using a microscope (Nikon Eclipse E 600).

Statistical analysis. Statistical analysis was performed with the Student's unpaired t test, with statistical significance set at ${ }^{*} \mathrm{P}<0.05,{ }^{* *} \mathrm{P}<0.01$ and ${ }^{* * *} \mathrm{P}<0.001$.

\section{Results}

TLC analysis was performed to investigate the phytochemical profiles of the extracts. Berberine was found to be a major constituent seen in all the extracts as a yellow fluorescence spot detected under UV $366 \mathrm{~nm}$ and an orange spot detected with Dragendroff's spraying reagent (Fig. 1A). The spot for berberine in the sample was confirmed by comparing the Rf value $(0.53)$ and the spectrum of the spot with that of the standard. Peak purity of the sample was fully in conformity with the standard (Fig. 1B). The berberine contents of 80ET, DCM and WF expressed as the mean \pm SD were $18.45 \pm 1.39$, 18.02 \pm 1.03 , and $17.95 \pm 0.97(\% \mathrm{w} / \mathrm{w})$, respectively. In the DCM fraction, other compounds, which may be alkaloid compounds, were observed as a blue fluorescent zone under UV $366 \mathrm{~nm}$ and an orange zone with Dragendroff's spraying reagent at $\mathrm{R} f 0.79$ (Fig. 1A).

To investigate the effects of the stem extract (80ET), its two fractions (WF and DCM) and its major constituent berberine on cell viability on the human colorectal carcinoma HCT-116 cell line, the cells were treated with $10-100 \mu \mathrm{g} / \mathrm{ml}$ of $80 \mathrm{ET}$ and WF, $1-100 \mu \mathrm{g} / \mathrm{ml}$ of DCM, and $1-50 \mu \mathrm{M}$ of berberine for 24,48 and $96 \mathrm{~h}$. The reduction in cell proliferation in a doseand time-dependent manner in response to the treatments is shown in Fig. 2A. At 24 h, a marked reduction in viability was detected with the concentration of $100 \mu \mathrm{g} / \mathrm{ml}$ of 80ET (26.55\%) and WF (37.27\%). After 96 h, all the higher dose treatments significantly inhibited cell growth $(\mathrm{P}<0.001)$. It is evident that all the treatments had a cytotoxic effect on the HCT-116 cell line, and that cell growth arrest was induced, in part, by apoptosis as assessed by caspase activity (Fig. 2B). As shown in Fig. 2C, the 24-h treatment with the extract, its fractions and berberine increased NAG-1 and ATF3 expression and strongly suppressed cyclin D1 expression in a dose-dependent manner. Protein expression was further examined in another colorectal cancer cell line, SW480. Cyclin D1 suppression by all the treatments was similar to that seen in HCT-116 cells, whereas ATF3 and NAG-1 induction was seen only in DCM-treated samples (Fig. 2D).

We also examined whether compounds in 80ET, DCM, $\mathrm{WF}$ and berberine bind to PPAR $\gamma$ as a ligand. PPAR $\gamma$ ligands are capable of binding to the PPAR $\gamma$ transcription factor, which then forms a heterodimeric complex with retinoid $\mathrm{X}$ receptor that functions as a central regulator of differentiation and a modulator of cell growth. Using a reporter system, HCT-116 cells were plated in 12-well plates and transfected with four copies of a Gal4 binding site (pMH100x4-TK-Luc) and chimeric receptors (pCMX-Gal4-mPPAR $\gamma$-LBD) (Fig. $3 \mathrm{~A})$. After the cells were treated with $10-100 \mu \mathrm{g} / \mathrm{ml}$ of $80 \mathrm{ET}$ and WF, $1-100 \mu \mathrm{g} / \mathrm{ml}$ of DCM and $1-50 \mu \mathrm{M}$ of berberine for $24 \mathrm{~h}$, luciferase activity was measured to assess transactivation for the PPAR $\gamma$ receptor. As shown in Fig. 3B, RGZ $5 \mu \mathrm{g} / \mathrm{ml}$, a positive control, demonstrated a 40 -fold increased induction, while DCM 10 and 100 showed 2.2- and 24.4-fold inductions of PPAR $\gamma$ ligand binding activity, respectively. However, 80ET, WF and low doses of berberine treatments did not show dramatic induction in activity. Therefore, the DCM fraction 
A

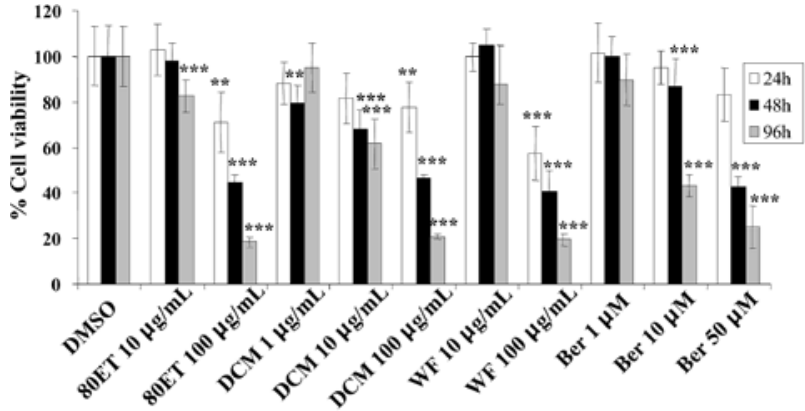

C

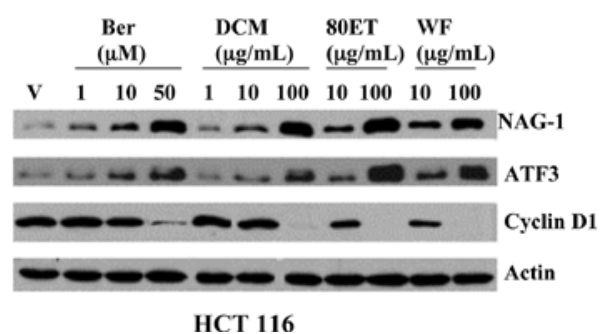

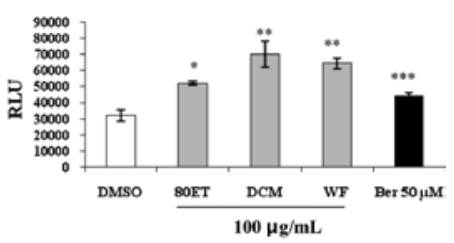

D

$50 \mu \mathrm{M} 100 \mu \mathrm{g} / \mathrm{mL}$

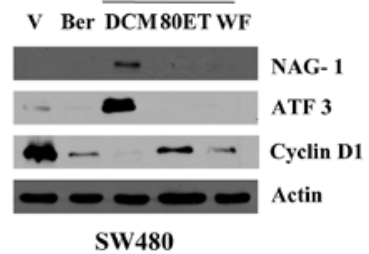

Figure 2. Effect of 80ET, DCM, WF and berberine on percent cell viability and protein expression. (A) HCT-116 cells were treated with vehicle or various concentrations of 80ET, DCM, WF and berberine for 4 days. Cell growth was measured using the CellTiter96 Aqueous One solution cell proliferation assay. Values are expressed as the mean $\pm \mathrm{SD}$ of six replicates. ${ }^{* *} \mathrm{P}<0.01 ;{ }^{* * *} \mathrm{P}<0.001$ vs. DMSO-treated cells. (B) Apoptosis detection (caspase $3 / 7$ activity). HCT-116 cells were treated with the indicated compounds for $24 \mathrm{~h}$. Caspase 3/7 activity was measured as described in Materials and methods. The data represent the mean \pm SD from three independent experiments. The y-axis represents relative luciferase unit (RLU). (C and D) Western blot analysis of NAG-1, ATF3 and cyclin D1 expression in HCT-116 cells (C) and SW480 cells (D) treated with berberine, DCM, 80ET and WF for 24 h. Total protein (30 $\mu \mathrm{g})$ was subjected to 14\% SDS-PAGE and antibodies for NAG-1, ATF3, cyclin D1 or actin were applied as described in Materials and methods.

\section{A pCMX-Gal4-mPPAR $\gamma$-LBD}

CMX Gal4 DBD

pMH100X4-TK-Luc

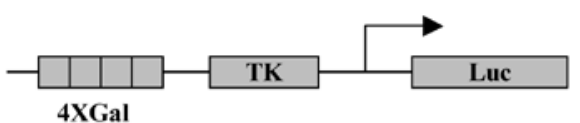

4XGal

B

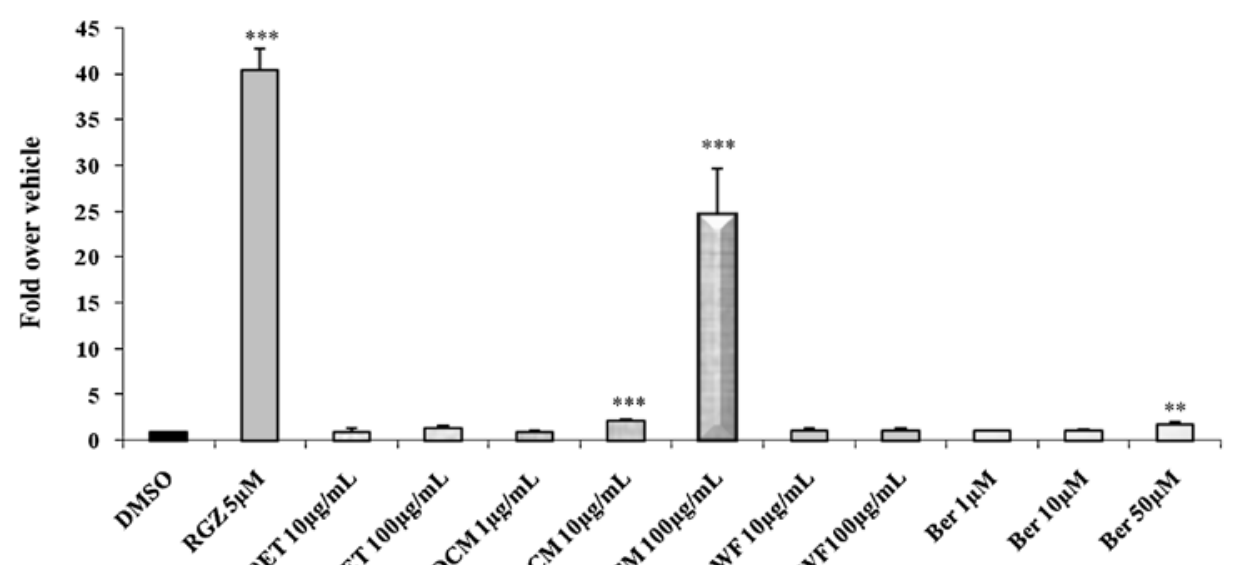

Figure 3. PPAR $\gamma$ ligand binding activity of 80ET, DCM, WF and berberine. (A) Schematic diagram of pCMX-Gal4-mPPAR $\gamma$-LBD and pMH100X4-TK-Luc vector. (B) HCT-116 cells were plated at $1 \times 10^{5}$ cells/well in 12-well plates and were transiently transfected with MH100x4-TK-LUC and chimeric receptor pCMX-Gal-mPPAR $\gamma$-LBD. Cells were treated with vehicle and various concentrations of the extracts and berberine for $24 \mathrm{~h}$, and luciferase activity was measured. Data are presented as relative luciferase activity (firefly luciferase signal/renilla luciferase signal). Results show the mean \pm SD of three independent transfections. The y-axis represents fold induction over DMSO-treated samples. ${ }^{* *} \mathrm{P}<0.01 ;{ }^{* * * *} \mathrm{P}<0.001$ vs. vehicle-treated cells. (C) 3T3-L1 cell differentiation. 3T3-L1 cells were differentiated in the presence or absence of DCM $(50 \mu \mathrm{g} / \mathrm{ml})$ to adipocyte. The cells were stained with oil-red O at day 9 as described in Materials and methods. 
may exclusively contain a compound that facilitates PPAR $\gamma$ activity of this plant. Finally, we examined the effect of DCM fraction on 3T3-L1 cell differentiation and found an elevated fat accumulation as assessed by oil-red O staining (Fig. 3C), indicating that DCM treatment increases PPAR $\gamma$ activation during adipocyte differentiation.

\section{Discussion}

Natural products have played an important role in drug discovery and development. Specifically, C. fenestratum is a widely used medicinal plant in Southeast Asia (27). The major constituents of the stem are protoberberine alkaloids such as berberine, palmatine and jatrorrhizine (26,28-30). In folkloric medicine, people favor the use of the stems and roots of $C$. fenestratum rather than the leaves due to their greater alkaloid content. Previous study has shown that the stem of $C$. fenestratum exerts an anti-proliferative effect against lung carcinoma and/ or the lung metastatic cell lines A549, LLC and B16-BL6 via the induction of morphological change and DNA fragmentation (31). Our study showed that the extracts of this plant, including 80ET, DCM, WF and berberine, inhibit cell proliferation and further provide potential targets in colorectal cancer. NAG-1 and ATF3 have pro-apoptotic and anti-tumorigenic activities in colorectal cancer cells and other cell lines $(3,8,9,32)$. Of note, both ATF3 and NAG-1 are induced by the green tea catechin ECG and by indole-3-carbinol treatment, supporting the concept that ATF3 and NAG-1 play a role in phytochemicalinduced apoptosis and are important molecular target proteins of chemopreventive compounds. In addition, all three extracts and berberine strongly reduced cyclin D1 expression in HCT-116 and SW480 cells. Cyclin D1 plays a role in the regulation of cell growth (33), and plant-derived compounds effectively block cell cycle progression by inhibiting the expression of cyclin D1 $(32,34,35)$. Since all the extracts showed a similar effect on antiproliferation, berberine may be one of the active constituents causing cyclin D1 suppression. However, only DCM increases both NAG-1 and ATF3 expression in SW480 cells (Fig. 2D). The difference between SW480 and HCT-116 cells is p53 expression. Wild-type p53 gene is expressed in HCT-116 cells, whereas SW480 cells produce a mutant p53 gene. Thus, 80ET and WF increase NAG-1 and ATF3 expression via p53 tumor suppressor proteins, whereas DCM may have the activity to increase NAG-1 and ATF3 expression in a p53-independent manner. Indeed, both NAG-1 and ATF3 are known to be regulated by $\mathrm{p} 53$ tumor suppressor protein at the transcription level $(36,37)$.

In this study, we demonstrated that the DCM fraction exhibited considerable PPAR $\gamma$-binding activity and the induction of pro-apoptotic genes. Although Yin et al reported that berberine is capable of exerting a glucose-lowering effect in hepatocytes that is insulin independent, similar to that of metformin, and can stimulate apoptosis in several cancer cells (38), our data strongly suggest that berberine is a weak PPAR $\gamma$ ligand and NAG-1/ATF3 inducer, compared to the DCM fraction (Figs. 2 and 3B). This suggests that components in the DCM fraction play a role in anti-proliferative activity through PPAR $\gamma$ binding ability. Further studies are required to clarify the molecular mechanisms of individual compounds from the DCM fraction.
In conclusion, this study provides information on the antiproliferative effect of $C$. fenestratum. Berberine may be an active constituent of the plant, possessing anti-proliferative activity. However, the DCM fraction shows improved antiproliferation activity in colorectal cancer cells. The DCM fraction of the $C$. fenestratum stem extract appears to be a most promising fraction for consideration as an anti-tumorigenic agent in future cancer management.

\section{Acknowledgements}

We thank Misty R. Bailey (University of Tennessee) for her critical reading of the manuscript. This work was supported by the Center of Excellence in Livestock Diseases and Human Health from the University of Tennessee. Financial support for P. Rojsanga was provided by the Royal Golden Jubilee Ph.D. Program (PHD/0235/2544), Thailand.

\section{References}

1. Wattanathorn J, Uabundit N, Itarat W, Mucimapura S, Laopatarakasem P and Sripanidkulchai B: Neurotoxicity of Coscinium fenestratum stem, a medicinal plant used in traditional medicine. Food Chem Toxicol 44: 1327-1333, 2006.

2. Punitha IS, Rajendran K, Shirwaikar A and Shirwaikar A: Alcoholic stem extract of Coscinium fenestratum regulates carbohydrate metabolism and improves antioxidant status in streptozotocin-nicotinamide induced diabetic rats. Evid Based Complement Alternat Med 2: 375-381, 2005.

3. Baek SJ, Kim KS, Nixon JB, Wilson LC and Eling TE: Cyclooxygenase inhibitors regulate the expression of a TGF-beta superfamily member that has proapoptotic and antitumorigenic activities. Mol Pharmacol 59: 901-908, 2001.

4. Martinez JM, Sali T, Okazaki R, Anna C, Hollingshead M, Hose C, Monks A, Walker NJ, Baek SJ and Eling TE: Drug-induced expression of nonsteroidal anti-inflammatory drug-activated gene/macrophage inhibitory cytokine-1/prostate-derived factor, a putative tumor suppressor, inhibits tumor growth. J Pharmacol Exp Ther 318: 899-906, 2006.

5. Baek SJ, Kim JS, Jackson FR, Eling TE, McEntee MF and Lee SH: Epicatechin gallate-induced expression of NAG-1 is associated with growth inhibition and apoptosis in colon cancer cells. Carcinogenesis 25: 2425-2432, 2004.

6. Baek SJ, Wilson LC and Eling TE: Resveratrol enhances the expression of non-steroidal anti-inflammatory drug-activated gene (NAG-1) by increasing the expression of p53. Carcinogenesis 23: 425-434, 2002.

7. Piyanuch R, Sukhthankar M, Wandee G and Baek SJ: Berberine, a natural isoquinoline alkaloid, induces NAG-1 and ATF3 expression in human colorectal cancer cells. Cancer Lett 258: 230-240, 2007.

8. Lee SH, Cekanova M and Baek SJ: Multiple mechanisms are involved in 6-gingerol-induced cell growth arrest and apoptosis in human colorectal cancer cells. Mol Carcinog 47: 197-208, 2008.

9. Cho KN, Sukhthankar M, Lee SH, Yoon JH and Baek SJ: Green tea catechin (-)-epicatechin gallate induces tumour suppressor protein ATF3 via EGR-1 activation. Eur J Cancer 43: 2404-2412, 2007.

10. Lu D, Wolfgang CD and Hai T: Activating transcription factor 3, a stress-inducible gene, suppresses Ras-stimulated tumorigenesis. J Biol Chem 281: 10473-10481, 2006.

11. Alao JP: The regulation of cyclin D1 degradation: roles in cancer development and the potential for therapeutic invention. Mol Cancer 6: 24, 2007.

12. Arber N, Sutter T, Miyake M, Kahn SM, Venkatraj VS, Sobrino A, Warburton D, Holt PR and Weinstein IB: Increased expression of cyclin $\mathrm{D} 1$ and the $\mathrm{Rb}$ tumor suppressor gene in c-K-ras transformed rat enterocytes. Oncogene 12: 1903-1908, 1996.

13. Ratschiller D, Heighway J, Gugger M, Kappeler A, Pirnia F, Schmid RA, Borner MM and Betticher DC: Cyclin D1 overexpression in bronchial epithelia of patients with lung cancer is associated with smoking and predicts survival. J Clin Oncol 21: 2085-2093, 2003. 
14. Huang JW, Shiau CW, Yang YT, Kulp SK, Chen KF, Brueggemeier RW, Shapiro CL and Chen CS: Peroxisome proliferator-activated receptor gamma-independent ablation of cyclin D1 by thiazolidinediones and their derivatives in breast cancer cells. Mol Pharmacol 67: 1342-1348, 2005.

15. Deep G, Singh RP, Agarwal C, Kroll DJ and Agarwal R: Silymarin and silibinin cause G1 and G2-M cell cycle arrest via distinct circuitries in human prostate cancer PC 3 cells: a comparison of flavanone silibinin with flavanolignan mixture silymarin. Oncogene 25: 1053-1069, 2006.

16. Stepulak A, Sifringer M, Rzeski W, Endesfelder S, Gratopp A, Pohl EE, Bittigau P, Felderhoff-Mueser U, Kaindl AM, Buhrer C, Hansen HH, Stryjecka-Zimmer M, Turski L and Ikonomidou C: NMDA antagonist inhibits the extracellular signal-regulated kinase pathway and suppresses cancer growth. Proc Natl Acad Sci USA 102: 15605-15610, 2005.

17. Barak Y, Nelson MC, Ong ES, Jones YZ, Ruiz-Lozano P, Chien KR, Koder A and Evans RM: PPAR gamma is required for placental, cardiac, and adipose tissue development. Mol Cell 4: 585-595, 1999.

18. Bren-Mattison Y, van Putten V, Chan D, Winn R, Geraci MW and Nemenoff RA: Peroxisome proliferator-activated receptorgamma [PPAR(gamma)] inhibits tumorigenesis by reversing the undifferentiated phenotype of metastatic non-small cell lung cancer cells (NSCLC). Oncogene 24: 1412-1422, 2005.

19. Vignati S, Albertini V, Rinaldi A, Kwee I, Riva C, Oldrini R, Capella C, Bertoni F, Carbone GM and Catapano CV: Cellular and molecular consequences of peroxisome proliferator-activated receptor-gamma activation in ovarian cancer cells. Neoplasia 8: 851-861, 2006

20. Elstner E, Muller C, Koshizuka K, Williamson EA, Park D, Asou H, Shintaku P, Said JW, Heber D and Koeffler HP: Ligands for peroxisome proliferator-activated receptorgamma and retinoic acid receptor inhibit growth and induce apoptosis of human breast cancer cells in vitro and in BNX mice. Proc Natl Acad Sci USA 95: 8806-8811, 1998

21. Baek SJ, Wilson LC, Hsi LC and Eling TE: Troglitazone, a peroxisome proliferator-activated receptor gamma (PPAR gamma) ligand, selectively induces the early growth response-1 gene independently of PPAR gamma. A novel mechanism for its anti-tumorigenic activity. J Biol Chem 278: 5845-5853, 2003

22. Sarraf P, Mueller E, Smith WM, Wright HM, Kum JB, Aaltonen LA, De la Chapelle A, Spiegelman BM and Eng C: Loss-of-function mutations in PPAR gamma associated with human colon cancer. Mol Cell 3: 799-804, 1999.

23. Cekanova M, Yuan JS, Li X, Kim K and Baek SJ: Gene alterations by peroxisome proliferator-activated receptor gamma agonists in human colorectal cancer cells. Int J Oncol 32: 809-819, 2008.

24. Yamaguchi K, Lee SH, Eling TE and Baek SJ: A novel peroxisome proliferator-activated receptor gamma ligand, MCC-555, induces apoptosis via posttranscriptional regulation of NAG-1 in colorectal cancer cells. Mol Cancer Ther 5: 1352-1361, 2006.
25. Rungsimakan S: Pharmacognostic Properties of Khamin Khruea. Department of Pharmacognosy, Chulalongkorn University, Bangkok, p188, 2001.

26. Rojsanga P, Gritsanapan W and Suntornsuk L: Determination of berberine content in the stem extracts of Coscinium fenestratum by TLC densitometry. Med Princ Pract 15: 373-378, 2006.

27. Wongcome T, Panthong A, Jesadanont S, Kanjanapothi D, Taesotikul $\mathrm{T}$ and Lertprasertsuke $\mathrm{N}$ : Hypotensive effect and toxicology of the extract from Coscinium fenestratum (Gaertn.) Colebr. J Ethnopharmacol 111: 468-475, 2007.

28. Malhotra S, Taneja SC and Dhar KL: Minor alkaloids from Coscinium fenestatum. Phytochemistry 28: 1998-1999, 1989.

29. Pinho PMM, Pinto MMM, Kijjoa A, Pharadai K, Diaz JG and HerZ W: Protoberberine alkaloids from Coscinium fenestratum. Phytochemistry 31: 1403-1407, 1992.

30. Siwon J, Verpoorte R, van Essen GFA and Baerheim Svendsen A: Studies on Indonesian medicinal plants III. The alkaloids of Coscinium fenestratum. Planta Med 38: 24-32, 1980.

31. Ueda JY, Tezuka Y, Banskota AH, Le Tran Q, Tran QK, Harimaya Y, Saiki I and Kadota S: Antiproliferative activity of Vietnamese medicinal plants. Biol Pharm Bull 25: 753-760, 2002.

32. Baek SJ, Okazaki R, Lee SH, Martinez J, Kim JS, Yamaguchi K, Mishina Y, Martin DW, Shoieb A, McEntee MF and Eling TE: Nonsteroidal anti-inflammatory drug-activated gene-1 over expression in transgenic mice suppresses intestinal neoplasia. Gastroenterology 131: 1553-1560, 2006.

33. Morgan DO: Principles of CDK regulation. Nature 374: 131-134, 1995.

34. Shukla S and Gupta S: Apigenin-induced cell cycle arrest is mediated by modulation of MAPK, PI3K-Akt and loss of cyclin D1 associated retinoblastoma dephosphorylation in human prostate cancer cells. Cell Cycle 6: 1102-1114, 2007.

35. Lim YC, Lee SH, Song MH, Yamaguchi K, Yoon JH, Choi EC and Baek SJ: Growth inhibition and apoptosis by (-)-epicatechin gallate are mediated by cyclin D1 suppression in head and neck squamous carcinoma cells. Eur J Cancer 42: 3260-3266, 2006.

36. Baek SJ, Wilson LC and Eling TE: Resveratrol enhances the expression of non-steroidal anti-inflammatory drug-activated gene (NAG-1) by increasing the expression of p53. Carcinogenesis 23: 425-432, 2002.

37. Yan C, Jamaluddin MS, Aggarwal B, Myers J and Boyd DD: Gene expression profiling identifies activating transcription factor 3 as a novel contributor to the proapoptotic effect of curcumin. Mol Cancer Ther 4: 233-241, 2005.

38. Yin J, Hu R, Chen M, Tang J, Li F, Yang Y and Chen J: Effects of berberine on glucose metabolism in vitro. Metabolism 51: 1439-1443, 2002. 